DOI: $10.17516 / 1997-1370-0604$

УДК $316.35,304.442$

\title{
Methodology for the Study of Complex Identity
}

\author{
Anna A. Shpak and Daria S. Pchelkina* \\ Siberian Federal University \\ Krasnoyarsk, Russian Federation
}

Received 05.03.2020, received in revised form 30.04.2020, accepted 08.05.2020

\begin{abstract}
The article is devoted to the study of methods for the formation of complex social identities in the semiotic context of culture. On the basis of empirical and theoretical material, the article describes modern provisions regarding social identities. The interconnection of personal and group identities and the features of their interaction with each other are noted. Based on an analytical review of theories of complex social identities, methods for constructing them are proposed. The concept of culture presented in this article as a landmark system is based on the classical and modern research. Cultural memory is presented as a factor constructing self-awareness. The main factors of constructing a complex ethnocultural identity, the authors include cultural mechanisms. The article is based on studies of the subjective and objective languages of the literary text of culture.
\end{abstract}

Keywords: social identity, complex identity, ethnicity, ethnocultural groups, sign systems, cultural mechanisms.

The study was carried out with the financial support of the Russian Foundation for Basic Research in the framework of the scientific project No. 19-39-90041.

Research area: culturology.

Citation: Shpak, A.A., Pchelkina, D.S. (2020). Methodology for the study of complex identity. J. Sib. Fed. Univ. Humanit. Soc. Sci., 13(5), 752-761. DOI: 10.17516/1997-1370-0604.

\footnotetext{
(C) Siberian Federal University. All rights reserved

* Corresponding author E-mail address: annaheyy@gmail.com, pchelkina.ml@mail.ru ORCID: 0000-0002-2948-8762 (Shpak)
} 
The methodology for the formation of complex identities in this article will be considered primarily from the broad concept of social identity itself. The emphasis in this case is shifted to the combination of an ethnic identity with other social identities.

Turning to the study of the problems of social identity, it is necessary to note its interdisciplinary nature that determines the relationship between an individual and various social groups. In sociology, the study of identity is associated with a feature of the social functioning of an individual as a result of the action of social mechanisms of individual self-determination. Identity issues in sociological research were dealt with by such authors as H. Becker, P. Berger, P. Bourdieu, I. Hoffman, T. Luckmann, R. Merton, R. Turner, and others.

\section{Types of Social Identity}

Formation of identity ensures the integration, wholeness and unity of self-awareness of a personality as a complex individual. Identity in sociology is seen from the point of view of a social phenomenon accessible to the empirical approach, since it is the effect of various social institutions on the self-determination of a person. Identity as a complex entity manifests itself at the cognitive, semantic, and affective levels (Biankina, 2017). With this approach, social ideological systems are studied from the point of view of social institutions, which in turn form a personal identity. This approach analyses the impact of external factors, that is, society, state and professional environment, on a personality, as well as the reaction of this personality to this impact.

Let us point out the classification of types of identity proposed by S. Huntington: cultural, political, ascriptive, social, territorial, and economic (Huntington, 2008).

According to Z.A. Zhade, E.S. Kukva, S.A. Liaushev, A.Iu. Shadzhe, the sociological approach analyses personal and collective identities and their interconnection as a bidirectional process of society's self-identification, in which some contradictions between collective and individual identification are possible (Zhade et al., 2006).
D.S. Mart'ianov notes that the concept of social identity "describes how other people define a person based on broad social categories or characteristics, such as age, profession or ethnicity. These are the components of an "I" person that a person experiences at the level of awareness of belonging to any group" (Mart'ianov, 2015).

Social identity, given the above factors, is the determination of an individual through his belonging to certain social groups. Societies and communities, in turn, have a collective identity.

According to A.V. Mikliaev and P.V. Rumiantseva, an interdisciplinary nature involves the consideration of the phenomenon of identity as a social process determined by the sociocultural situation of society. The concept of social identity is associated with a person's self-determination on the basis of various social categories and signs, through which a person reckons himself in a specific group, which means social comparison (Mikliaeva, Rumiantseva 2008).

S. Moscovici, J. Habermas are developing a theory of social representations through the concept of identity balance. The concept of equivalence of identities presented by J. Habermas considers personal identity through the reflection of connections of a person's personal experience, while social identity reflects the fulfilment of various social roles. A person is in search of a compromise between the two aspects of identity. J. Habermas' study of the phenomenon of identity through a personal category involves focusing on the diversity of groups that include an individual. As for the social category, it is seen as the identity of an individual with one or another group (Habermas, 1999).

The characteristics of the concept of social identity are such properties as relationality, collectivity, sociality, diversity (Semenenko, 2017).

Considering identity from the point of view of sociology, it is worth noting its division into a personal and group type. Personal and group identities are inextricably interconnected, and personal identity, in turn, is formed by both internal and external factors. The formation of personality identity through external factors occurs through various social groups. 
As I.V. Lysak and L.F. Kosenchuk note, personal identity has two main approaches to the problem of determination. The first approach involves personal identification as a mechanism that promotes the formation of identity, and identity, in turn, is the result of this process. The second approach is based on the statement about the processuality of the phenomenon of identity itself. These approaches differ in the role of the personal "I" of an individual in the process of identity formation.

\section{Concepts of complex cultural identity}

Theories related to the consideration of complex social identities can be noted as studies on the positive attitude of intergroup interactions with predominance of complex social identities of an individual. The development of these theories is based on the model of complex social identity of a personality proposed by S. Roccas and M. Brewer (Roccas, Brewer, 2002), which represents four types of complex identities: "intersection", "predominance", "fragmentation", "merging", where the emphasis is shifted toward the prevalence of complex identity in an individual subject, not a social group, and the development of G.V. Bodenhausen's theory, which is based on the types of $\mathrm{S}$. Roccas and M. Brewer, but identifies three patterns of functioning of a complex identity: "dominance", "division" , "integration." In the latter theory, the emphasis is put on solving conflicting group problems. Attention, as in the previous case, is focused on a complex identity of a personality (Bodenhausen, 2009). The publication of O.E. Khukhlaev and M.A. Khait (Khukhlaev, Khait, 2012) sets out the basic principles of this theory, which distinguishes several types of complex social identities: "intersection", "predominance", "fragmentation", "merging". "Intersection" is a type of identity when a person relates himself to any social group, and it, in turn, combines two or more groups, and only if all the significant social characteristics of the group are present, the individual relates himself to this group. The second type of "predominance" is when an individual has many identities, there is one that is predominant. The third type is "fragmentation," when, depending on a specific situation, an individual in various social groups selects one that is most suitable. The single social whole of personal identities breaks up showing the sides necessary in a given situation. The fourth type is "merging". In this type the whole complexity of the identities that a personality has is equally significant. However, as M.B. Brewer notes in his article "The Complexity of Social Identity and Acceptance of Diversity," individuals in complex communities have multiple social groups that have some categories of intersection with each other, but this position may not reduce intra-group prejudice and discrimination. More likely, it is precisely the subjective representation of the complexity of identity that matters for intergroup relations. It is necessary to mention a property of duality of identity, in connection with the simultaneous desire to have characteristics that are similar and different from differentiated social groups. Variability of identity is a hallmark.

N.K. Steffens, Małgorzata A. Gocłowska, and A.D. Galinsky examine the positive impact of complex identity on the creative potential of an individual. Having multiple social identities is associated with the increased creative potential through cognitive flexibility (Steffens et al., 2015).

In connection with the positive settings in the study of complex social identities, the question of their construction and formation in a social environment of modern society arises. In this case, it is necessary to turn to the symbolic direction of research in the field of cultural studies. The cognitive approach is to examine culture through the prism of signs and symbols. The symbolic direction in culturological research is based on the cultural theory of Clifford Geertz, in which culture is the production and use of symbolic forms (Geertz, 2004). It means that cultural systems are formed through symbols, that is, culture itself is considered as a space of symbolic forms. The interconnection of such symbols can have a dual meaning: expression and reproduction of reality, and its construction. Since culture is viewed through symbolic forms, we can talk about the formation of ethnocultural groups. Ethnocultural groups, viewed through the prism of signs and symbols, allow the emergence of such a con- 
cept as cultural mechanisms that use cultural texts having certain consequences and effects on complex social groups.

Turning to the study of identity, some authors point out only two main approaches: primordialism (historical conditionality and innate nature of certain characteristics of identity) and constructivism (identity has a focused nature aimed at certain manipulations with different social groups). Ethnologist M.N. Guboglo notes the difference only in the development factors of a community - internal mechanisms or external management. Also, one of the approaches in ethnic self-identification is an instrumental approach that is characterized by the fact that the belonging to an ethnic group itself can be used as a growth resource in various spheres of social activity. Belonging to one or another identity is considered as a social capital. In the study of ethnicity, constructivism is a basic analytical approach, the followers of which are B. Anderson, P. Bourdieu, E. Gellner, E. Hobsbawm, V. Tishkov. According to primordialism, ethnicity as a category has only objective grounds independent of human self-awareness. Ethnic identity, in turn, according to the constructivist approach, can be interpreted as a product and result of social relations between people. Thus, ethnic identity has a dynamic nature, in which transformational processes can occur. In scientific literature, some researchers distinguish the following approaches to the problems of identity formation: essentialism (includes a primordial set of properties and qualities), constructivist approach (identity is regarded as a social construct), as well as constructive realism (identity has stable and constructive components with a conscious and unconscious nature) (Lysak, Kosenchuk, 2016).

\section{Methodology of the study of complex social identities}

The modern era with a large number of social transformations leads to strengthening of the role of social construction of identities. To a greater extent, this statement can be traced at the regional, civil, national, ethnic, digital levels, through state apparatuses. For example, V.A. Tishkov notes the following in relation to national identity: "a nation is not only the result of ethnocultural unification, but the result of the deliberate influence of the political and intellectual elite on establishing ideas about people as a nation, common values and symbols of culture" (Tishkov, 1994; Sertakova, 2013).

The construction of a complex identity is associated with the possibility of a comprehensive impact on a personality from a psychological point of view. "Smart" and "soft" forces of influence on society are associated with cultural practices aimed at human consciousness and reproduce cultural codes, signs and symbols that determine individual's membership in a particular ethnocultural group (Berezhnova and Pimenova, 2015; Kistova et al., 2016; Reznikova, 2012; Zamaraeva, 2014).

Ethnosocial and ethnocultural processes record the degree of foundation of traditional cultural structures and changes in axiological characteristics and ethnicity parameters from local and general sides. On the general side, it is worth noting the processes of heterogenization as exacerbation of such phenomena as ethnogenesis, ethnic interest, ethnic culture, and ethnic roots (Avdeeva et al., 2019a; Koptseva, 2014; Koptseva et al., 2018; Koptseva and Reznikova, 2015; Libakova et al., 2016; Zamaraeva et al., 2019a, 2019b; Zhgunova, Ivanova, 2011).

The formation of a complex identity ensures integration, integrity and unity of self-awareness of a person as a complex individual. The instruments of the constructivist approach include categorization, situational actions, cognitive meanings, projects, actions, events, social institutions (Kashaf, 2014).

Dividing the methodological approaches into narrow and broad ones, we can say that the broad approaches are determined by the analysis of literature, inductive approach and conceptual analysis, but narrow approaches are mainly sociological.

Considering the broad approaches through comparing various statistics, one can note the development of ethnosociology in the Soviet period of the 1980's. This area has been studying the problems of interethnic relations and ethnic identity. Ethnosociology has developed three levels of relationships: institutional, 
intergroup, and interpersonal (Dugin, 2011). Broad methods also include the historiographic method, which is determined primarily by the descriptive characteristics of the phenomena of identity.

Considering the narrow methods of constructing a complex identity, we can distinguish the sociological approaches that are formed using semiotic systems, as noted earlier. Based on the concepts of sign systems, we can conclude that they can reproduce, produce and transform. When studying ethnocultural groups, the stability of their components should be designated.

We also should consider a comparative method, since the very nature of identity presupposes comparison of an I individual and the Other (Habermas, 1999). Identification and comparison are a simultaneous process, which in the framework of design means the need to ensure the continuity of this process in the formation of a complex identity. In this case, reflection is precisely the process in which the formation of identity takes place. Comprehension of identity and formation of self-consciousness through comparing an individual and the other lead to the integrity of the individual's perception of himself, that is personal identity. When determining the formation of cultural identity, it is worth noting the cultural comparison determined by some cultural differences in sociocultural societies. In this case - through certain symbolic forms: language, values, historical memory, religion, traditions, national character (Galkina, 2010; Kolesnik, 2018; Koptseva et al., 2012; Pchelkina, 2015).

The method of constructing psychosemantic spaces, as noted by A.I. Popova and S.G. Maksimova, helps to correlate the subjective experiences of a personality and the methods of consciousness developed by society through language forms (Popova, Maksimova, 2018). Mentioning the features of language in the formation of an ethnocultural group, it is worth noting the presence of a special set of concepts.

Turning to the definition of culture as production and reproduction of symbolic forms, it is necessary to consider the cultural mechanisms of constructing complex identities.
The elements of culture do not exist outside of human activities, and therefore, in Clifford Geertz's theory, culture has a set of such control mechanisms as cultural programs that control an individual's behaviour (Kovalenko, 2010).

In the structure of the mechanism of formation of one or another identity, N.V. Ivanova distinguishes two aspects: cognitive and affective. The affective aspect is a positive or negative emotional attitude towards any group, while the cognitive aspect includes identification awareness and self-identification with a social group, and knowledge about the differences between one's own and another social groups will be a constituent (Zhgunova, Ivanova, 2011). Differentiation is based on the awareness of the "in" and "out" groups about the difference in certain signs of a social group.

On the basis of semitic systems, a category of memory as a mechanism for constructing identity arises. Memory has an impact on the development of traditional culture to a greater extent because it acts as "the only system of codification of information within the boundaries of the primitive stage of the society development" (Kostina, 2013). Memory as a tradition contains an objective side of the cultural and historical process. In the context of cultural memory, spiritual and material culture can be considered from a syncretic point of view determined by the totality of experience. A tradition acts as a norm pervading the past and influencing modern relations both within the group and outside it. Iu. Lotman indicated that, in canonical cultures, the reproduction of a cultural text leads to the formation of a new information field. The tradition, in turn, reproducing and supporting the existing social system, renews the values, ideas, stereotypes, customs and rites of an ethno-cultural group. Social mechanisms used in the ethnocultural space are aimed at preserving the sign system in its immutability and stability. They are divided into one or another degree of regimentation into more or less rigid ones. One of the ways of expressing regimentation, which is less regulated and demonstrates more desire than a ban, is folklore that has an instructive character. Turning to the definition of cultur- 
al memory, according to Assmann, "culture is the objective memory of society, preserving its identity and transmitting it along the chain of generations. The forms, in which society organizes the transfer of information necessary to preserve the given identity, and the institutions that care about the transfer of such information, denote the uniqueness and the unique style of a particular culture" (Assmann, 2004).

\section{Cultural mechanisms}

\section{for constructing complex identities}

When considering the cultural mechanisms of constructing complex identities, it is necessary to note the symbolic and sign systems of representing different cultural meanings through a comparison of the subject and object characteristics of formulas. There are intra-system mechanisms of detailed representation of complex cultural knowledge in the folklore formulas (Dobrova, 2018).

N.M. Libakova, N.N. Pimenova, A.V. Kistova explore artistic, ceremonial culture, folk life, rituals as a constructive element of ethnic identity. N.A. Safonova considers a traditional ritual culture as a cultural mechanism for the preservation of ethnocultural identity. The signs of the phenomenon of ethnocultural identity are distinguished as follows: a territorial sign, a cultural component and language. Ritual practice, as a mechanism, regulates the processes of ethnocultural identity (Safonova, 2016). A.V. Kistova considers complex ethnic identities as belonging of an individual to different ethnic groups, provided that the individual simultaneously understands the differences and integrates their values (Avdeeva et al., 2019b; Kistova, 2013; Kolesnik et al., 2019; Reznikova et al., 2019).

Distinguishing such a constructive element of culture as a work of art, the catego- rial apparatus associated with this definition should be designated. According to the theory of N.P. Koptseva and V.I. Zhukovskii, a work of art is defined as a thing of the second nature, which is created artificially and have material dimensions. Its purpose is creating an artistic image aimed at uniting human and Absolute principles. The artistic image, in turn, includes the concept of art space as a meeting place for a person-spectator and a work-thing. It is the artistic space that is interesting to consider from the point of view of constructing identity as the space of an artistic text. This space includes certain artistic signs that make it possible to trace a complex identity in them by referring to the object and subject of language (Kolesnik et al., 2018; Koptseva, Zhukovskii, 2004; Semenova, 2010; Seredkina et al., 2019; Shimanskaia and Koptseva, 2018).

Works of art contain an extensive ethnic memory and a spiritual experience of generations. For complex identities, the connection of various ethnic symbols is typical, but at the same time, the equivalence of different ethnic and cultural groups is traced. In turn, social identities combined with ethnocultural identity have positive characteristics for the self-determination of an individual in society. The constructing cultural mechanism is considered from the semiotic point of view of the subject and object languages of an artistic text of culture.

Thus, the indicated conceptual foundations for the study of the phenomenon of complex identities allow us to highlight the features of ethnic identity in the system of social sciences. The study of methodology identifies some qualitative methods for the study of complex identities, while cultural mechanisms focus on various cultural texts.

\section{References}

Assmann, Ia. (2004). Kul'turnaya pamiat': Pis'mo, pamiat'o proshlom i politicheskaia identichnost'v vysokikh kul'turakh drevnosti [Cultural memory: Writing, memory of the past and political identity in high cultures of antiquity], $370 \mathrm{p}$.

Avdeeva, Iu.N., Degtiarenko, K.A., Koptseva, N.P., Pchelkina, D.S., Shimanskaia, K.I., Shpak, A.A. (2019b). Spetsifika religioznogo soznaniia ketov i sel'kupov v kontekste kul'turnogo i istoricheskogo 
razvitiia [The specificity of religious consciousness of the Kets and Selkups in the context of cultural and historical development]. In Severnye Arkhivy i Ekspeditsii [Northern Archives and Expeditions], 3 (3), 63-80.

Avdeeva, Iu.N., Degtiarenko, K.A., Pchelkina, D.S., Shimanskaia, K.I., Koptseva, N.P., Shpak, A.A. (2019a). Religion of the Selkups and the Kets in the historical and cultural genesis. In Zhurnal SFU. Gumanitarnye nauki [Journal of SibFU. Humanities \& Social Sciences], 12 (5), 726-751.

Berezhnova, M.I., Pimenova, N.N. (2015). Migratsiia kak sredstvo razvitiia territorii: istoricheskii primer Kolymskogo kraia [Migration as a means of territorial development: a historical example of the Kolyma region]. In Sovremennye problemy nauki i obrazovaniia [Modern problems of science and education], 1-1, 1886.

Biankina, O.S. (2017). Formirovanie grazhdanskoi identichnosti v molodezhnoi srede [Formation of civil identity in the youth environment]. In Molodezhnye zabaikal'skie sotsiologicheskie chteniia. IV Nauchno-prakticheskaia konferentsiia, 8-12.

Bodenhausen, G.V. (2009). Diversity in the person, diversity in the group: Challenges of identity complexity for social perception and social interaction. In European Journal of Social Psychology Eur. J. Soc. Psychol, 40, 1-16.

Dobrova, S.I. (2018). Vnutriurovnevye semioticheskie mekhanizmy reprezentatsii kul'turnykh smyslov $\mathrm{v}$ fol'klornykh formulakh [Intra-level semiotic mechanisms of representation of cultural meanings in folklore formulas]. In Lingvofol'kloristika, 28(1), 14-22.

Dugin, A.G. (2011). Etnosotsiologiia [Ethnosociology], 639 p.

Galkina, A.E. (2010). Rol' sopostavitel'nogo metoda v formirovanii natsional'no-kul'turnoi identichnosti [The role of the comparative method in the formation of national and cultural identity]. In Vestnik Krasnoiarskogo gosudarstvennogo pedagogicheskogo universiteta im. V.P. Astaf'eva, 3, 140-144.

Geertz, K. (2004). Interpretacija kul'tur [Interpretation of culture], $11 \mathrm{p}$.

Habermas, J. (1999). V poiskakh natsional'noi identichnosti. Filosofskie i politicheskie stat'i [In search of a national identity. Philosophical and political articles], $252 \mathrm{p}$.

Huntington, S. (2008). Kto my? Vyzovy amerikanskoi natsional'noi identichnosti [Who are we? Challenges to American national identity], $637 \mathrm{p}$.

Kashaf, Sh.R. (2014). Polisub"ektnoe konstruirovanie natsional'no-gosudarstvennoi identichnosti v novykh granitsakh politicheskogo soobshchestva Rossii: krymskii kazus [Poly-subject construction of national and state identity in the new borders of the political community of Russia: Crimean incident]. In Severo-Kavkazskii iuridicheskii vestnik, 2, 64-71.

Khukhlaev, O.E., Khait M.A. (2012). Slozhnost' sotsial'noi identichnosti: kontseptsiia S. Rokass i M. Briuer [Complexity of social identity: the concept of S. Rocass and M. Brewer]. In Sotsial'naia psikhologiia i obshchestvo, 3, 16-26.

Kistova, A.V. (2013). Konstruirovanie etnokul'turnoi i obshchenatsional'noi identichnostei na osnove etnograficheskogo podkhoda v sotsial'noi filosofii [Constructing ethnocultural and national identities based on the ethnographic approach in social philosophy]. In Dokt, Diss., $22 \mathrm{p}$.

Kistova, A.V., Moskaliuk, M.V., Sertakova, E.A., Dvoretskaia, A.P. (2016). Ispol'zovanie imeni Vasiliia Ivanovicha Surikova v konstruirovanii polozhitel'nogo obraza goroda Krasnoiarska [Using the name of Vasily Ivanovich Surikov in the construction of a positive image of the city of Krasnoyarsk]. In NB: Administrativnoe pravo i praktika administrirovaniia [NB: Administrative law and practice of administration], 6, 1 - 13. DOI: 10.7256/2306-9945.2016.6.20967. Available at: https://nbpublish.com/library_read_article. php?id=20967

Kolesnik, M.A. (2018). Filosofskie aspekty poniatiia "kul'turnaia identichnosti" [Philosophical aspects of the concept of "cultural identity"]. In Sibirskii antropologicheskii zhurnal [Siberian Anthropological Journal], 2 (2), 22-33.

Kolesnik, M.A., Leshchinskaia, N.M., Sertakova, E.A. (2019). Obraz poeta-tvortsa v simvolizme Giustava Moro [Image of the poet-creator in the symbolism of Gustave Moreau]. In Sibirskii antropologicheskii zhurnal [Siberian Anthropological Journal], 4 (12), 25-37. 
Kolesnik, N.M., Libakova, N.M., Sertakova, E.A. (2018). Art education as a way of preserving the traditional ethnocultural identity of the indigenous minority peoples from the North, Siberia and the Far East. In Science for education, 8 (4), 233-247.

Koptseva, N.P. (2014). Ekspertnyi analiz osnovnykh tendentsii ekonomicheskogo razvitiia korennykh malochislennykh narodov Severnoi Sibiri [Expert analysis of the main trends in the economic development of the indigenous peoples of Northern Siberia]. In Economic Annals-XXI, 11-12, 93-96.

Koptseva, N.P., Amosov, A.E., Il'beikina, M.I., Evseenko, E.A., i dr. (2018). Novye proekty dlia vozrozhdeniia evenkiiskogo iazyka i kul'tury [New projects for the revival of the Evenki language and culture]. Krasnoyarsk, Sibirskii federal'nyi universitet, 246 p.

Koptseva, N.P., Pimenova, N.N., Luzan, V.S., Semenova, A.A., Sertakova, E.A., Bakhova, N.A. (2012). Ethno-Formative Mechanisms and Forms of Self-Awareness of the Indigenous Peoples Under Conditions of External Civilization Pressure (by an Example of the Yakut Ethnic Group). In Journal of Siberian Federal University. Humanities \& Social Sciences, 7 (5), 988-1004.

Koptseva, N.P., Reznikova, K.V. (2015). Refinement of the causes of ethnic migration of the north Selkups based on the historical memory of the indigenous ethnic groups in Turukhansk district of Krasnoyarsk krai. In Bylye Gody, 38 (4), 1028-1038.

Kostina, A.V. (2013). Pamiat' kak mekhanizm kul'tury [Memory as a mechanism of culture]. In Kul'tura i obrazovanie, $1(10), 47-53$.

Kovalenko, E.M. (2010). Kul'tura kak ob"ektivirovannaia sistema znachenii v simvolicheskoi kontseptsii Klifforda Girtsa [Culture as an objectified system of meanings in the symbolic concept of Clifford Geertz]. In Nauchnaia mysl' Kavkaza, 2, 17-21.

Libakova, N.M., Sertakova, E.A., Kolesnik, M.A., Sitnikova, A.A., Il'beikina, M.I. (2016). Sovremennye strategii sotsial'nogo pozitsionirovaniia Sibirskikh regionov [Modern strategies of social positioning of the Siberian regions]. In Sotsiodinamika [Sociodynamics]. 1, 162-189. DOI: 10.7256/2409-7144.2016.1.17420. Available at: http://e-notabene.ru/pr/article_17420.html

Lysak, I.V., Kosenchuk, L.F. (2016). Formirovanie personal'noi identichnosti v usloviyakh setevoi kul'tury [Formation of personal identity in the conditions of network culture]. $147 \mathrm{p}$.

Margulian, Ia.A. (2015). Sotsiokul'turnye faktory ukrepleniia natsional'noi identichnosti [Sociocultural factors of strengthening national identity]. In Trudy Sankt-Peterburgskogo gosudarstvennogo instituta kul'tury, 206, 170-174.

Mart'ianov, D.S. (2015). Slozhnaia identichnost' v global'nom obshchestve [Complex identity in global society]. In Nauchnyi al'manakh, 8 (10), 1440-1442.

Mikliaeva, A.V., Rumiantseva, P.V. (2008). Sotsial'naia identichnost' lichnosti: soderzhanie, struktura, mekhanizmy formirovaniia: Monografiia [Social identity of the individual: content, structure, mechanisms of formation: Monograph], 129-133.

Pchelkina, D. (2015). Mekhanizm formirovaniia lichnostnoi interpretatsii v sotsial'nom prostranstve khudozhestvennoi kul'tury [The mechanism for formation of personal interpretation in the social space of art culture]. In Sotsiodinamika [Sociodynamics], 8, 38-63. DOI: 10.7256/2409-7144.2015.8.16108. Available at: https://nbpublish.com/library_read_article.php?id=16108

Reznikova, K.V., Sitnikova, A.A., Zamaraeva, Iu.S. (2019). Filosofiia iskusstva v tvorchestve Egona Shile [The philosophy of art in the work of Egon Schiele]. In Sibirskii antropologicheskii zhurnal [Siberian Anthropological Journal], 4 (12), 38-48.

Reznikova, K.V. (2012). Sotsial'noe konstruirovanie obshchenatsional'noi identichnosti v Rossiiskoi Federatsii [Social construction of national identity in the Russian Federation]. In Dokt, Diss., 20 p.

Popova, A.I., Maksimova, S.G. (2018). Psikhosemanticheskii analiz formirovaniia etnicheskoi identichnosti na primere skazok Germanii [Psychosemantic analysis of the formation of ethnic identity on the example of fairy tales in Germany]. In Sotsial'naia integratsiia i razvitie etnokul'tur v evraziiskom prostranstve, 6 (1), 367-374.

Roccas, S., Brewer, M.B. (2002). Social identity complexity. Personality and Social Psychology Review, 6, 88-10. 
Safonova, N.A. (2016). Traditsionnaia obriadovaia kul'tura kak mekhanizm sohraneniia etnokul'-turnoi identichnosti [Traditional ritual culture as a mechanism for preserving ethnocultural identity]. In Vestnik Chelyabinskoi gosudarstvennoi akademii kul'tury i iskusstv, 3 (47), 55-59.

Semenenko, I.S. (2017). Identichnost': Lichnost', obshchestvo, politika. Entsiklopedicheskoe izdanie [Personality, society, politics. Encyclopedic edition], 992 p.

Semenova, A.A. (2010). Modern Practices of Foresight Research of the Future of Social-Anthropological Systems, Including Ethnical Cultural Populations. In Journal of Siberian Federal University. Humanities \& Social Sciences, 5 (3,) 667-676.

Seredkina, N.N., Kistova, A.V., Pimenova. N.N. (2019). Tri kartiny Edvarda Munka: filosofsko-iskusstvovedcheskii analiz tsikla "Friz zhizni" [Three paintings by Edvard Munch: philosophical and art history analysis of the cycle "Frieze of life"]. In Sibirskii antropologicheskii zhurnal [Siberian Journal of Anthropology], 4 (12), 49-64.

Sertakova, E.A. (2013). Sotsial'nyi konstruktivizm kak teoriia konstruirovaniia etnosa [Social constructivism as a theory of ethnic design]. In Sovremennye problemy nauki i obrazovaniia [Modern problems of science and education], 6, 999.

Shimanskaya, K.I., Koptseva, N.P. (2018). Istoriograficheskii obzor korennykh issledovanii za 20142018 gg. [Historiographic review of indigenous research for 2014-2018]. In Sibirskii antropologicheskii zhurnal [Siberian Journal of Anthropology], 2, (01), 43-57.

Steffens, N.K., Małgorzata A. Gocłowska, Galinsky, A.D. (2015). How Multiple Social Identities Are Related to Creativity. In Personality and Social Psychology Bulletin 1-16 by the Society for Personality and Social Psychology.

Tishkov, V.A. (1994). Rossiia kak mnogonatsional'naia obshchnost' i perspektiva mezhetnicheskogo soglasiia [Russia as a multinational community and the prospect of inter-ethnic harmony]. In Rossiiskie issledovaniia, seriia: Politologiia, (4), 30 p.

Zamaraeva, Iu.S., Luzan, V.S., Metliaeva, S.V., Seredkina, N.N., Fil'ko, A.I., Khrebtov, M.Ia. (2019b). Rol' religii v sokhranenii traditsionnogo obraza zhizni evenkov. In Severnye Arkhivy i Ekspeditsii, 3 (3), 34-47.

Zamaraeva, Iu.S. (2014). Osobennosti etnicheskoi migratsii v sotsial'no-psikhologicheskom vospriiatii (na materiale analiza rezul'tatov eksperimenta po metodike "Seriinye tematicheskie assotsiatsii") [Features of ethnic migration in the socio-psychological perception (based on the analysis of the results of the experiment according to the technique of "Serial thematic associations")]. In Sotsiodinamika [Sociodynamics], 9, 63-82. DOI: 10.7256/2306-0158.2014.9.13407. Available at: https://nbpublish.com/library_read_article. php?id=13407

Zamaraeva, Iu.S., Luzan, V.S., Metliaeva, S.V., Seredkina, N.N., Koptseva, N.P., Fil'ko, A.I., Khrebtov, M.Ia. (2019a). Religion of the evenki: history and modern times. In Zhurnal SFU. Gumanitarnye nauki [Journal of SibFU. Humanities \& Social Sciences], 12 (5), 853-871.

Zhade, Z.A., Kukva, E.S., Liausheva, S.A. (2006). Mnogourovnevaia identichnost' [Multilevel identity], $241 \mathrm{p}$.

Zhgunova, M.A., Ivanova, N.V. (2011). Etnokul'turnaia identichnost' russkikh: sovremennye problemy izucheniia i sokhraneniia [Ethnocultural identity of Russians: modern problems of studying and preserving]. In Fenomen identichnosti v sovremennom gumanitarnom znanii. K 70-letiiu akademika V.A. Tishkova, 337-350.

Zhukovskii, V.I., Koptseva, N.P. (2004). Propozitsii teorii izobrazitel'nogo iskusstva [Propositions of the theory of fine art], $265 \mathrm{p}$. 


\title{
Методология исследований сложной идентичности
}

\author{
A.А.Шпак, Д.С. Пчелкина \\ Сибирский федеральный университет \\ Российская Федерация, Красноярск
}

\begin{abstract}
Аннотация. Статья посвящена исследованию методов формирования сложных социальных идентичностей в семиотическом контексте культуры. На основе эмпирического и теоретического материала в статье дается описание современных положений, касающихся социальных идентичностей. Отмечается взаимосвязь личностной, персональной идентичности и групповой особенности их взаимодействия друг с другом. На основе аналитического обзора теорий сложных социальных идентичностей предлагаются способы их конструирования. Представленное в данной статье понятие культуры как знаковой системы опирается на классические и современные исследования. Культурная память представлена как конструирующий самосознание фактор. К основным факторам конструирования сложной этнокультурной идентичности авторы относят культурные механизмы. Основа данного исследования базируется на изучении субъективного и объективного языков художественного текста культуры.
\end{abstract}

Ключевые слова: социальная идентичность, сложная идентичность, этничность, этнокультурные группы, знаковые системы, культурные механизмы.

Исследование выполнено при финансовой поддержке РФФИ в рамках научного проекта № 19-39-90041.

Научная специальность: 24.00 .00 - культурология. 